\title{
A Rarely Seen Pathology in Breast Masses: Malignant Melanoma
}

\author{
Meme Kitlelerinde Nadir Bir Patoloji: Malign Melanom
}

Hande Köksal', Ersin Turan', ilknur Küçükosmanoğlu², Arif Atay', Mustafa Karaağaç3, Meryem i..Eren Karanis² Osman Doğru'

\footnotetext{
${ }^{1}$ Sağlık Bilimleri University, Konya Education and Research Hospital, Department of General Surgery, Konya, Turkey

${ }^{2}$ Sağlık Bilimleri University, Konya Education and Research Hospital, Department of Pathology, Konya, Turkey

${ }^{3}$ Sağlık Bilimleri University, Konya Education and Research Hospital, Department of Internal Medicine, Konya, Turkey
}

\section{ABSTRACT}

Although primary breast carcinoma is one of the most common malignancies among women worldwide, metastasis of any kind of tumor to the breast is rarely seen. Herein, a 64 year-old woman, who was operated for malignant melanoma before, with a solitary breast metastasis is reported to discuss diagnostic difficulties, treatment modalities and follow-up steps.

Key Words: Breast, malignant melanoma

Received: 12.03 .2016

Accepted: 04.07.2017
ÖZET

Memenin primer kanserleri kadınlarda görülen en sık kanserlerden biri olmasına rağmen, memeye metastaz nadir görülmektedir. Burada, daha önceden malign melanom nedeniyle ameliyat edilen 64 yaşındaki kadın hastada saptanan memede malign melanom metastazı tanıdaki zorluklar, tedavi yaklaşımları ve takip açısından tartışılmak üzere sunulmuştur.

Anahtar Sözcükler: Meme, malign melanom

Geliş Tarihi: $\quad 03.12 .2016$

Kabul Tarihi: 07.04.2017

\section{INTRODUCTION}

Although primary breast carcinoma is one of the most common malignancies among women worldwide, metastasis of any kind of tumor to the breast is rarely seen and varies from 1-5\%. The malignancies that metastasizing to the breast are malignant melanoma (MM), lymphoma, lung cancer and soft tissue sarcomas. Less than 5\% of MM cases have breast involvement and each differs from another by means of presenting symptom at the beginning and during the course of the disease (1). In this case, a 64 year-old woman, who was operated for MM before, with a solitary breast metastasis is reported to discuss diagnostic difficulties, treatment modalities and follow-up steps.

\section{CASE REPORT}

A 64 year-old woman was admitted to our breast center with a complaint of palpable left breast mass. It was learnt from her medical history that she was operated for malignant melanoma located on left scapula 10 months ago and received postoperative radiotherapy. On physical examination a painless, lobulated circumscribed mass located on upper outer quadrant of left breast was determined which was $2 \mathrm{~cm}$ in diameter. Breast ultrasound revealed a peripherally but superficially located, well circumscribed hypoechoic lesion at left breast 1 o'clock position, which was $14 \times 15 \mathrm{~mm}$ in size. Mammographically it was reported as hyper-dense, well-defined nodular opacity with dimensions of $24 \times 16 \mathrm{~mm}$, located at upper outer quadrant of left breast (Figure 1). The lesion was staged as radiological BIRADS 4 and biopsy was performed. 


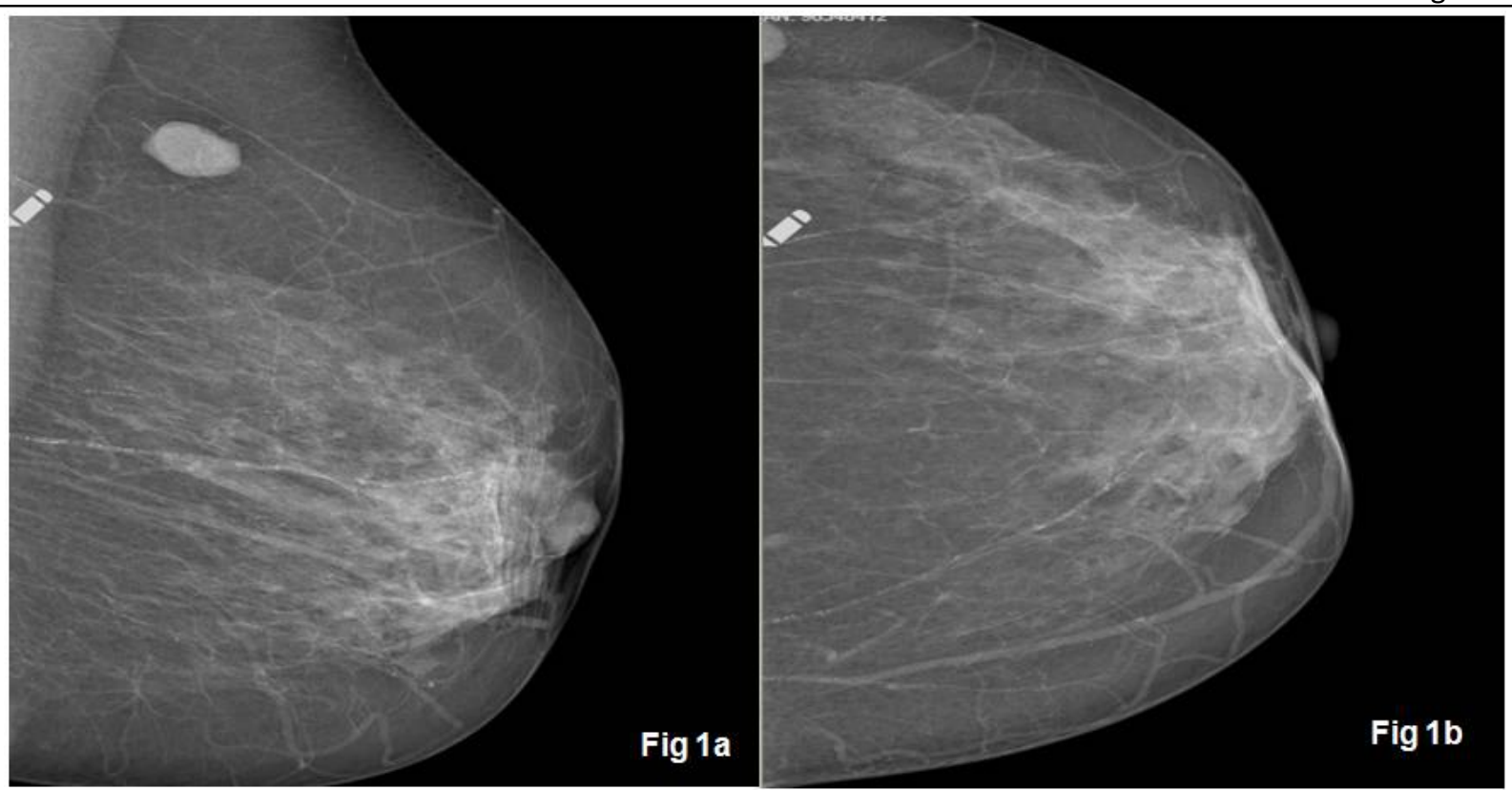

Figure 1a: Left breast, MLO mammogram, Figure 1b: Left breast, CC mammogram

After immunohistochemical staining "malignant melanoma metastasis" was reported (Figure 2). Because it was a unique lesion, for the best locoregional control breast conserving surgery and axillary dissection was performed after positive sentinel lymph node biopsy.
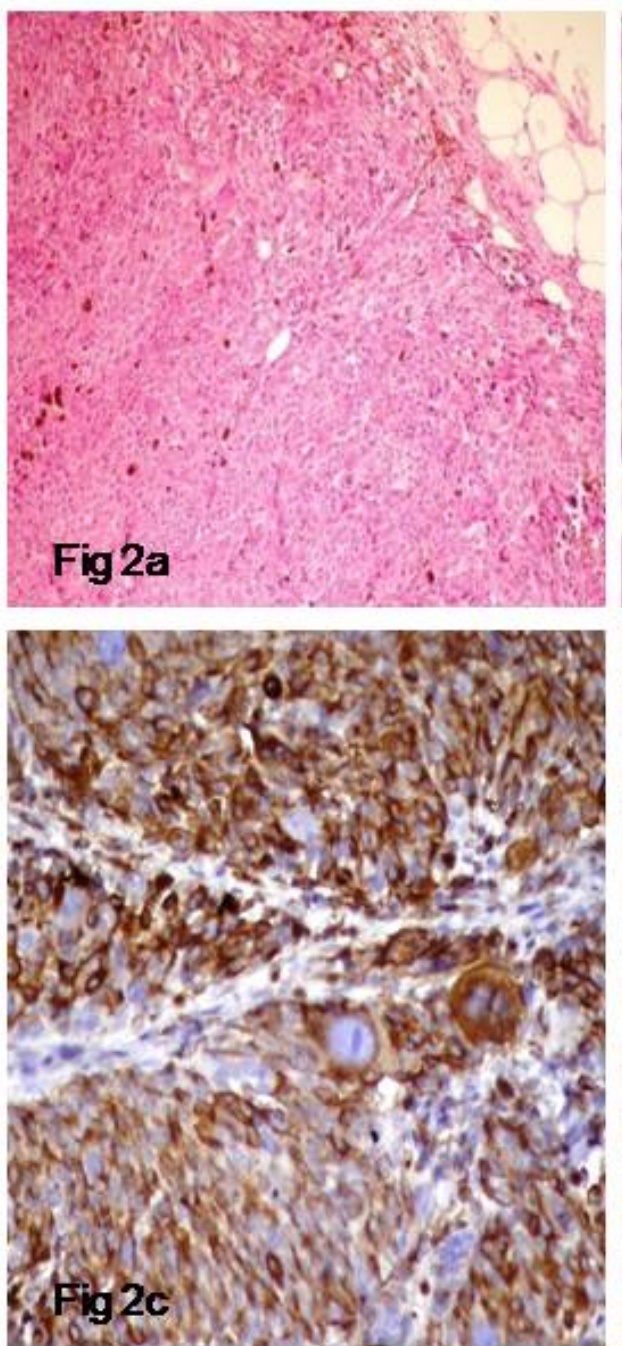

Chemotherapy regimen consisting of temozolomide was given after detection of negative BRAF gene mutation. She has been under follow-up with a progressive disease for 30 months.
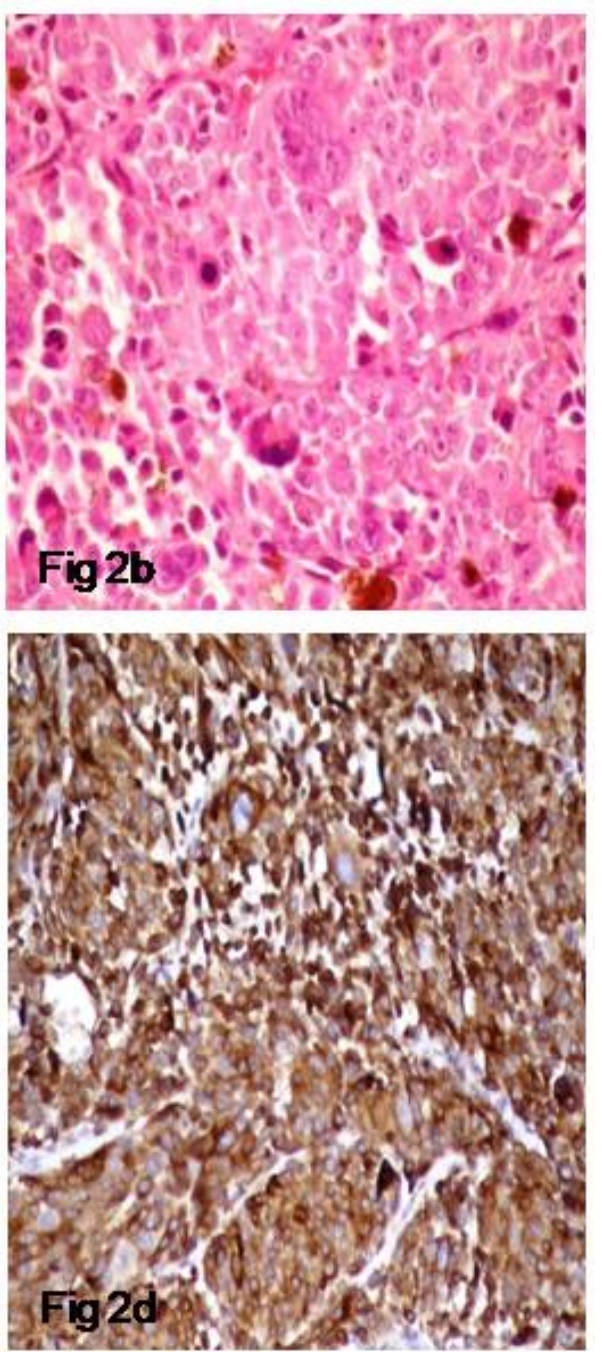

Figure 2a: Microscopic view of malignant melanoma: spindle cells forming fascicle like structures, nesting tumor cells with ovoid-round nucleus. (HEx100), Figure $\mathbf{2 b}$ Microscopic view of malignant melanoma: tumor cells with large nucleus and marked nucleolus, occasionally bizaar cells, giant cells, with high mitosis number and melanin pigment. (HEx400), Figure 2c: Melan-A positivity in tumor cells. (Melan-Ax400), Figure 2d: HMB-45 positivity in tumor cells.(HMB-45x400) 

DISCUSSION

Malignant melanoma is the second most common non-hematopoietic malignancy after carcinomas (2) and it shows different manifestations in the breast not only at initial presentation but also during the follow-up periods. Malignant melanoma and the breast can be interrelated in various ways as; primary melanoma of breast skin, melanoma metastasis to the breast, intransit metastasis to the breast tissue and breast skin, and finally primary breast melanoma (3-6). The decision; whether any mass in the breast is primary or metastatic; is of great significance for the subsequent choice of therapy. Although metastasis to breast of any kind of malignancy is rare, if it occurs it is usually the indicator of disseminated disease and poor prognosis. The median survival expectation is 10-11 months in metastasizing MM (1).

In any malignant melanoma case with a palpable breast mass, mammography and/or ultrasound should be obtained to reveal the number of metastatic lesions. The detection of bilateral breast metastases from melanoma is highly suggestive of metastatic multi-organ disease and can be useful to address the therapeutic approach (7). Fine-needle aspiration cytology is shown to be an excellent first line diagnostic modality when clinical data are known and if metastatic disease is suspected, the material obtained by fine-needle aspiration provides a definitive diagnosis and prevents open surgical biopsy or mastectomy (8). Following confirmation of histological diagnosis, wide local excision or quadrantectomy is sufficient for surgical treatment in cases with no evidence of multiple metastatic lesions in breast $(3,9-11)$. Axillary dissection is possible if a clinically and pathologically positive axillary lymph node is identified (12). Malignant melanoma patients with solitary metastasis may have more favorable outcomes when compared with the ones with massively infiltrated breast. So, special attention should be given during planning medical and surgical treatment.

\section{Conflict of interest}

No conflict of interest was declared by the authors.
REFERENCES

1. Arora R, Robinson WA. Breast metastases from malignant melanoma. J Surg Oncol. 1992; 50: 27-9.

2. Inouye $\mathrm{CM}$, Cimino-Mathews $A$, Eisner $D$, Rosenthal $D L$, VandenBussche CJ.Fine needle aspiration of metastatic melanoma presenting as bilateral breast cysts. Diagn Cytopathol. 2017 45:446-51.

3. Cangiarella J, Symmans WF, Cohen JM, et al. Malignant melanoma metastatic to the breast: a report of seven cases diagnosed by fine-needle aspiration cytology. Cancer. 1998; 84: 160-2.

4. Deshpande AH, Munshi MM, Lele VR, Bobhate SK. Aspiration cytology of extramammary tumors metastatic to the breast. Diagn Cytopathol. 1999; 21: 319-23.

5. Pressman PI. Malignant melanoma and the breast. Cancer. 1973; 31: 784-92.

6. Kurul S. Diffuse microscopic intransit metastases from malignant melanoma of the breast. Plast Reconstr Surg. 2000;106:513-4.

7. Moschetta $M$, Telegrafo $M$, Lucarelli NM, et al. Metastatic breast disease from cutaneous malignant melanoma. Int J Surg Case Repports. 2014; 5: 34-36.

8. Rodriguez-Gil Y, Perez-Barrios A, Alberti- Masgrau N, Garzon A, de Agustin P. Fine needle aspiration cytology diagnosis of metastatic nonhaematological neoplasms of the breast: a series of seven cases. Diagn Cytopathol. 2012; 40:297-304.

9. Plesnicar A, Kovac V. Breast metastases from cutaneous melanoma: a report of three cases. Tumori. 2000; 86: 170-3.

10. Siegelmann-Danieli $\mathrm{N}$, Cohen $\mathrm{HI}$, Ben-Izhack O. Malignant skin lesions. Case 1: nevoid malignant melanoma of the breast presenting as a contralateral breast metastasis. J Clin Oncol. 1999, 17: 3850-2

11. Mayayo Artal E, Gómez-Aracil V, Mayayo Alvira R, Azua-Romeo J, Arraiza A. Spindle cell malignant melanoma metastatic to the breast from a pigmented lesion on the back. A case report. Acta Cytol. 2004; 48: 387-90

12. Kurul $S$, Taş $F$, Büyükbabani $N$, et al. Different manifestations of malignant melanoma in the breast: a report of 12 cases and a review of the literature. Jpn J Clin Oncol. 2005; 35: 202-6. 